\title{
STRUKTURA BEZROBOCIA REJESTROWANEGO W WOJEWÓDZTWIE PODKARPACKIM A ZMIANY NA RYNKU TOWAROWYM
}

\begin{abstract}
W niniejszym opracowaniu analizie poddano zależność między rynkiem towarowym a strukturą bezrobocia w województwie podkarpackim. Głównym celem opracowania jest próba określenia kierunku i siły wpływu zmian koniunkturalnych na rynku towarowym na strukture bezrobotnych w analizowanym regionie. Strukturę bezrobotnych analizowano ze względu na: płeć, poziom wykształcenia, wiek oraz miejsce zamieszkania. Weryfikację wniosków wynikających z teoretycznej analizy wpływu zmian rynku towarowego na strukturę bezrobocia zaś dokonano na podstawie danych panelowych dla 25 powiatów województwa podkarpackiego w latach 2003-2011. Ponadto przedstawiono również prosty model teoretyczny, w którym przyrosty stóp bezrobocia rejestrowanego (w niniejszym artykule zastąpiono stopami wzrostu liczby bezrobotnych) w kolejnych latach uzależnione są od zarówno przeszłych wartości owych stóp, jak i stóp wzrostu wielkości produkcji na poziomie powiatów. Model estymowano, wykorzystując procedurę uzmienniania stałej (fixed effect), gdyż okazuje się, że struktura bezrobotnych na poziomie powiatów województwa podkarpackiego wykazuje się wysokim poziomem heterogeniczności przestrzennej, oraz stosując zerojedynkowe zmienne przełącznikowe. Wprowadzenie zmiennych przełącznikowych zaś wynika stąd, że odgrywają one rolę zmiennej korygującej oddziaływanie bezrobocia z poprzedniego okresu na zmianę bieżącej stopy wzrostu bezrobotnych i zależą od tego, czy poziom bezrobocia rósł lub malał.

W opracowaniu w punkcie drugim dokonano opisowej analizy struktury bezrobotnych w województwie podkarpackim w podziale na: płeć, poziom wykształcenia, wiek oraz miejsce zamieszkania. W punkcie trzecim przedstawiono prosty model teoretyczny zależności pomiędzy bezrobociem a rynkiem towarowym. Punkt czwarty zawiera wyniki estymacji równań wynikających z analiz teoretycznych. Opracowanie kończy podsumowanie oraz ważniejsze wnioski wynikające z rozważań.

Słowa kluczowe: bezrobocie, struktura bezrobocia, województwo podkarpackie.
\end{abstract}

\section{WPROWADZENIE}

Zagadnienia rynku pracy stanowią jeden z ciekawszych, a zarazem najbardziej problematycznych obszarów badań w ekonomii. Główną przyczyną tego jest przede wszystkim występowanie zjawiska wysokiego poziomu bezrobocia, a jednocześnie jego przestrzennego zróżnicowania zarówno na poziomie regionów (województw), jak i na poziomie wewnątrzregionalnym (powiatowym). Ponadto rynek pracy jest wyjątkowo wrażliwy na sytuacje kryzysowe w gospodarce, czego przykładem jest stosunkowo szybki wzrost stopy bezrobocia w Polsce od początku światowego kryzysu gospodarczego z 2008 r., mimo że rynek towarowy z dość dużym opóźnieniem zareagował na początkowe sygnały o nadchodzącej recesji.

\footnotetext{
${ }^{1}$ Dr Tomasz Misiak, Katedra Ekonomii, Politechnika Rzeszowska, Al. Powstańców Warszawy 8, 35-959 Rzeszów, e-mail: tmisiak@prz.edu.pl
} 
W opracowaniu analizie poddano problem zależności pomiędzy rynkiem towarowym a poziomem bezrobocia w województwie podkarpackim. Głównym celem artykułu jest określenie siły oraz kierunku wpływu zmian koniunkturalnych na rynku towarowym na ogólny poziom bezrobocia oraz na poszczególne grupy (strukturę) bezrobotnych w województwie podkarpackim. Zgodnie z przyjętym celem podjęto zatem próbę weryfikacji hipotezy głównej, według której elastyczność poszczególnych grup (wydzielonych ze względu na strukturę) bezrobotnych jest istotnie zróżnicowana względem produkcji sprzedanej przemysłu. Tak sformułowana hipoteza badawcza pozwoli na wyodrębnienie grup bezrobotnych, na które mają najsilniejszy bądź najsłabszy wpływ zmiany na rynku towarowym. Prawidłowe określenie grup bezrobotnych najbardziej podatnych na sytuację koniunkturalną na rynku towarowym może stanowić podstawę rekomendacji dla racjonalnego wykorzystania instrumentów polityki państwa $\mathrm{w}$ walce $\mathrm{z}$ bezrobociem, podnosząc ich efektywność.

Strukturę bezrobotnych w opracowaniu analizowano ze względu na: płeć, poziom wykształcenia, wiek oraz miejsce zamieszkania. Prowadzone analizy oparto na danych panelowych dla 25 powiatów województwa podkarpackiego w latach 2003-2011. W celu weryfikacji postawionej hipotezy badawczej wykorzystano proste statystyki opisowe oraz wyniki estymacji modelu wynikającego z prowadzonych analiz teoretycznych z wykorzystaniem procedury uzmienniania stałej (fixed effect) oraz zmiennych przełacznikowych.

\section{STRUKTURA BEZROBOCIA REJESTROWANEGO NA PODKARPACIU}

Województwo podkarpackie charakteryzuje się dość zróżnicowanym wewnętrznie rynkiem pracy. Można wyróżnić powiaty ze stosunkowo niską stopą bezrobocia, jak Rzeszów czy Krosno, ale jednocześnie występują powiaty bieszczadzki czy brzozowski, gdzie notowane stopy bezrobocia zaliczane są do jednych z najwyższych w kraju. Ponadto średnie płace brutto notowane w powiatach województwa podkarpackiego nie przekraczają średniej płacy brutto dla całej Polski (najwyższym poziomem płacy brutto cechuje się Rzeszów, gdzie płace brutto były zbliżone do średniej krajowej). Podkarpacie stanowi zatem ciekawy przekrój powiatów pod względem zarówno rynku pracy, jak i wytworzonej produkcji czy poziomu rozwoju społeczno-gospodarczego. W niniejszym punkcie dokonano analizy przede wszystkim struktury bezrobocia rejestrowanego w podziale na:

- płeć,

- wykształcenie,

- wiek,

- miejsce zamieszkania.

\subsection{Struktura bezrobocia ze względu na płeć}

W tabeli 1 oraz na rysunku 1 zestawiono dane dotyczące struktury bezrobocia rejestrowanego według płci. Okazuje się, że średnio w analizowanym okresie $53 \%$ bezrobotnych stanowiły kobiety, mężczyźni zaś - 47\%. Jednocześnie można zaobserwować, że w roku 2003 udział kobiet i mężczyzn wśród bezrobotnych był zbliżony do proporcjonalnego. W latach 2004-2008 udział kobiet w bezrobotnych ogółem wzrastał, osiągając najwyższy poziom (prawie 58\%) w 2007 r. W 2009 r. udział kobiet wśród bezrobotnych znów zbliżył się do poziomu 50\%, a następnie zaczął nieznacznie rosnąć, osiągając w 2011 r. poziom zbliżonym do średniego dla całego analizowanego okresu. Można zatem dojść do wniosku, że udział kobiet w bezrobotnych ogółem rósł w momencie, gdy stopa 
bezrobocia (dla całej Polski oraz ta notowana w województwie podkarpackim) charakteryzowała się tendencją malejąca, co było w dużej mierze spowodowane okresem dobrej koniunktury gospodarczej, kształtował się zaś na zbliżonym do proporcjonalnego, w okresie gdy stopy bezrobocia ogółem rosły (w okresie pogorszenia się koniunktury gospodarczej). Takie obserwowane zależności mogą sugerować, że rosnący udział kobiet w bezrobotnych ogółem, w okresie gdy stopy bezrobocia ogółem spadały, mógł być efektem tego, iż w okresach dobrej koniunktury więcej mężczyzn niż kobiet znajdowało zatrudnienie. Może to zatem oznaczać, że to grupa bezrobotnych mężczyzn była bardziej prokoniunkturalna.

Tabela 1. Udział kobiet i mężczyzn w wielkości bezrobocia na Podkarpaciu

\begin{tabular}{|c|c|c|c|c|c|c|}
\hline \multirow{2}{*}{ Lata } & \multicolumn{3}{|c|}{ Kobiety } & \multicolumn{3}{|c|}{ Mężczyźni } \\
\hline & $\mathbf{A}$ & B & $\mathrm{C}$ & $\mathbf{A}$ & B & $\mathrm{C}$ \\
\hline 2003 & $50,7 \%$ & $\begin{array}{c}46,4 \% \\
\text { jarosławski }\end{array}$ & $\begin{array}{l}57,3 \% \\
\text { Krosno } \\
\end{array}$ & $49,3 \%$ & $\begin{array}{l}42,7 \% \\
\text { Krosno } \\
\end{array}$ & $\begin{array}{c}53,6 \% \\
\text { jarosławski }\end{array}$ \\
\hline 2004 & $52,1 \%$ & $\begin{array}{c}46,3 \% \\
\text { jarosławski }\end{array}$ & $\begin{array}{c}57,9 \% \\
\text { Krosno } \\
\end{array}$ & $47,9 \%$ & $\begin{array}{c}42,1 \% \\
\text { Krosno } \\
\end{array}$ & $\begin{array}{c}53,7 \% \\
\text { jarosławski }\end{array}$ \\
\hline 2005 & $53,4 \%$ & $\begin{array}{c}48,2 \% \\
\text { jarosławski }\end{array}$ & $\begin{array}{c}58,6 \% \\
\text { mielecki }\end{array}$ & $46,6 \%$ & $\begin{array}{c}41,4 \% \\
\text { mielecki }\end{array}$ & $\begin{array}{c}51,8 \% \\
\text { jarosławski }\end{array}$ \\
\hline 2006 & $56,1 \%$ & $\begin{array}{c}50,5 \% \\
\text { lubaczowski }\end{array}$ & $\begin{array}{c}62,6 \% \\
\text { Krosno } \\
\end{array}$ & $43,9 \%$ & $\begin{array}{c}37,4 \% \\
\text { Krosno } \\
\end{array}$ & $\begin{array}{c}49,5 \% \\
\text { lubaczowski }\end{array}$ \\
\hline 2007 & $57,9 \%$ & $\begin{array}{c}50,1 \% \\
\text { lubaczowski }\end{array}$ & $\begin{array}{c}66,9 \% \\
\text { krośnieński }\end{array}$ & $42,1 \%$ & $\begin{array}{c}33,1 \% \\
\text { krośnieński }\end{array}$ & $\begin{array}{c}49,9 \% \\
\text { lubaczowski }\end{array}$ \\
\hline 2008 & $55,5 \%$ & $\begin{array}{c}47,6 \% \\
\text { lubaczowski }\end{array}$ & $\begin{array}{c}62,7 \% \\
\text { krośnieński }\end{array}$ & $44,5 \%$ & $\begin{array}{c}37,3 \% \\
\text { krośnieński }\end{array}$ & $\begin{array}{c}52,4 \% \\
\text { lubaczowski }\end{array}$ \\
\hline 2009 & $50,1 \%$ & $\begin{array}{c}46,2 \% \\
\text { lubaczowski }\end{array}$ & $\begin{array}{c}54,8 \% \\
\text { brzozowski }\end{array}$ & $49,9 \%$ & $\begin{array}{c}45,2 \% \\
\text { brzozowski }\end{array}$ & $\begin{array}{c}53,8 \% \\
\text { lubaczowski }\end{array}$ \\
\hline 2010 & $51,6 \%$ & $\begin{array}{c}46,1 \% \\
\text { lubaczowski }\end{array}$ & $\begin{array}{c}57,0 \% \\
\text { tarnobrzeski }\end{array}$ & $48,4 \%$ & $\begin{array}{c}43,0 \% \\
\text { tarnobrzeski }\end{array}$ & $\begin{array}{c}53,9 \% \\
\text { lubaczowski }\end{array}$ \\
\hline 2011 & $52,9 \%$ & $\begin{array}{c}48,9 \% \\
\text { lubaczowski }\end{array}$ & $\begin{array}{c}58,8 \% \\
\text { dębicki }\end{array}$ & $47,1 \%$ & $\begin{array}{c}41,2 \% \\
\text { dębicki }\end{array}$ & $\begin{array}{c}51,1 \% \\
\text { lubaczowski }\end{array}$ \\
\hline
\end{tabular}

A - średni udział dla województwa w poszczególnych latach; B - minimalny udział na poziomie powiatów; $\mathrm{C}$ - maksymalny udział na poziomie powiatów

Źródło: obliczenia własne na podstawie danych na stronie www.stat.gov.pl.

Rys. 1. Średni udział bezrobotnych kobiet i mężczyzn na Podkarpaciu w latach 2003-2011

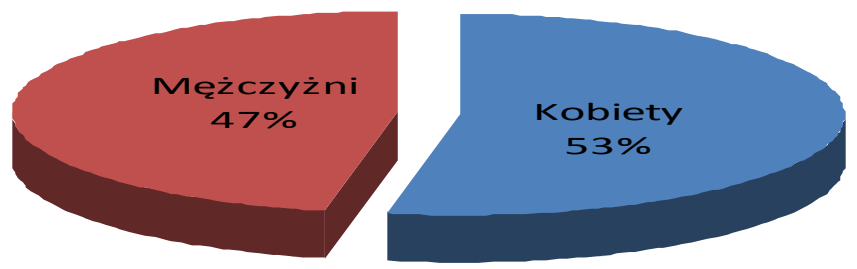

Źródło: opracowanie własne na podstawie danych w tabeli 1. 
Ponadto struktura bezrobotnych co do płci w województwie podkarpackim była również zróżnicowana przestrzennie. Maksymalne udziały kobiet notowano w powiatach ze stosunkowo niską stopą bezrobotnych ogółem, np. w powiecie Krosno, mieleckim czy dębickim, a minimalne w powiatach jarosławskim czy lubaczowskim, które charakteryzowały się wyższą ogólną stopą bezrobocia.

\subsection{Struktura bezrobocia ze względu na wykształcenie}

Analizując dane dotyczące struktury bezrobotnych ze względu na wykształcenie, zestawione w tabeli 2 i na rysunku 2, można natomiast zauważyć, że największy udział stanowiły osoby z wykształceniem zasadniczym zawodowym (około 1/3 wszystkich bezrobotnych). Bezrobotni z wykształceniem policealnym i średnim zawodowym oraz ci o najniższym poziomie wykształcenia (gimnazjalne i poniżej) stanowili po ok. 1/4 ogólnej liczby bezrobotnych. Najniższe udziały wśród wszystkich zarejestrowanych bezrobotnych odnotowano wśród bezrobotnych z wykształceniem wyższym (średnio 8,3\%) oraz z wykształceniem średnim ogólnokształcącym (średnio 8,8\%).

Rys. 2. Średnie udziały bezrobotnych ze względu na poziom wykształcenia w województwie podkarpackim

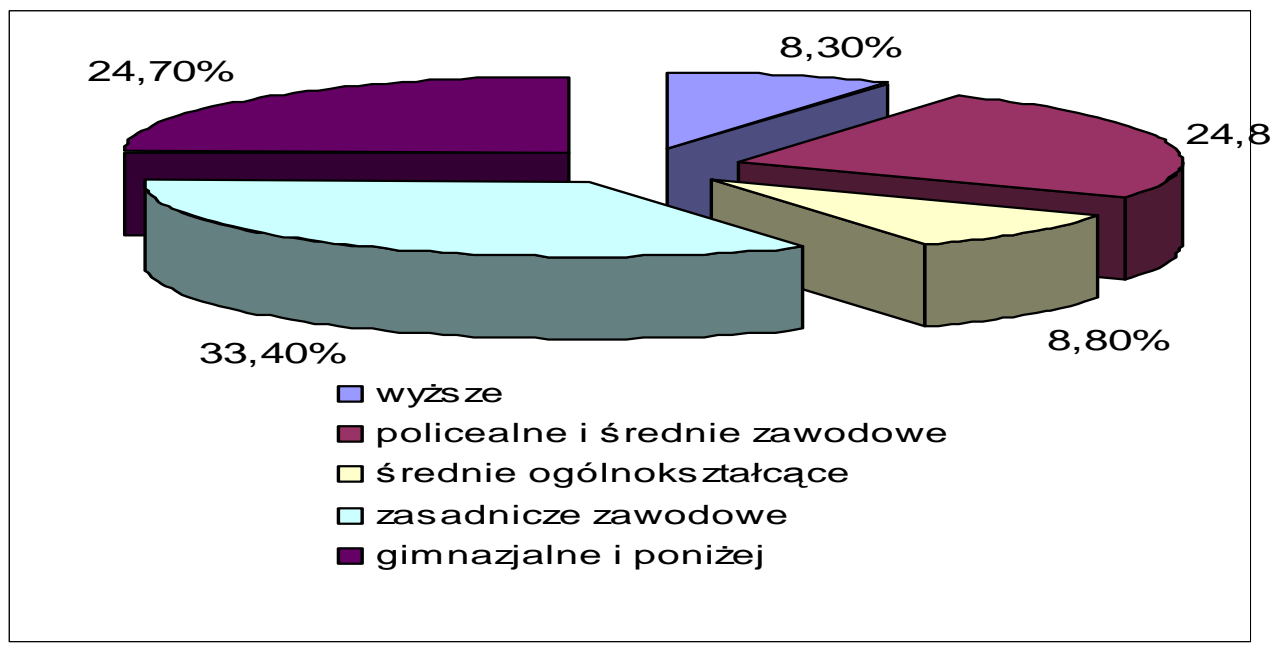

Źródło: opracowanie własne na podstawie danych z tabeli 2 
Struktura bezrobocia rejestrowanego...

Tabela 2. Struktura bezrobotnych ze względu na wykształcenie w województwie podkarpackim

\begin{tabular}{|c|c|c|c|c|c|c|c|c|c|}
\hline \multirow{2}{*}{ lata } & \multicolumn{3}{|c|}{ Wyższe } & \multicolumn{3}{|c|}{ Policealne i średnie zawodowe } & \multicolumn{3}{|c|}{ Średnie ogólnokształcące } \\
\hline & $\mathbf{A}$ & B & $\mathbf{C}$ & $\mathbf{A}$ & B & $\mathbf{C}$ & $\mathbf{A}$ & B & $\mathrm{C}$ \\
\hline 2003 & $4,9 \%$ & $\begin{array}{c}2,6 \% \\
\text { brzozowski }\end{array}$ & $\begin{array}{c}12,6 \% \\
\text { Rzeszów }\end{array}$ & $23,8 \%$ & $\begin{array}{c}18,8 \% \\
\text { mielecki }\end{array}$ & $\begin{array}{l}29,6 \% \\
\text { Krosno }\end{array}$ & $6,4 \%$ & $\begin{array}{c}3,7 \% \\
\text { brzozowski }\end{array}$ & $\begin{array}{c}12,8 \% \\
\text { Przemyśl }\end{array}$ \\
\hline 2004 & $5,5 \%$ & $\begin{array}{c}2,6 \% \\
\text { bieszczadzki }\end{array}$ & $\begin{array}{c}12,8 \% \\
\text { Rzeszów }\end{array}$ & $24,6 \%$ & $\begin{array}{c}20,0 \% \\
\text { bieszczadzki }\end{array}$ & $\begin{array}{l}29,5 \% \\
\text { Krosno }\end{array}$ & $6,9 \%$ & $\begin{array}{c}3,9 \% \\
\text { brzozowski }\end{array}$ & $\begin{array}{c}13,0 \% \\
\text { Przemyśl }\end{array}$ \\
\hline 2005 & $6,2 \%$ & $\begin{array}{c}3,3 \% \\
\text { bieszczadzki }\end{array}$ & $\begin{array}{c}14,0 \% \\
\text { Rzeszów }\end{array}$ & $24,7 \%$ & $\begin{array}{c}20,9 \% \\
\text { mielecki }\end{array}$ & $\begin{array}{l}29,6 \% \\
\text { Krosno }\end{array}$ & $7,7 \%$ & $\begin{array}{c}4,7 \% \\
\text { brzozowski }\end{array}$ & $\begin{array}{c}\text { 13,2\% } \\
\text { Przemyśl }\end{array}$ \\
\hline 2006 & $6,9 \%$ & $\begin{array}{c}3,8 \% \\
\text { bieszczadzki }\end{array}$ & $\begin{array}{c}15,3 \% \\
\text { Rzeszów }\end{array}$ & $24,4 \%$ & $\begin{array}{c}20,0 \% \\
\text { mielecki }\end{array}$ & $\begin{array}{l}30,5 \% \\
\text { Krosno }\end{array}$ & $8,3 \%$ & $\begin{array}{c}4,8 \% \\
\text { brzozowski }\end{array}$ & $\begin{array}{c}13,3 \% \\
\text { Przemyśl }\end{array}$ \\
\hline 2007 & $7,8 \%$ & $\begin{array}{c}4,1 \% \\
\text { bieszczadzki }\end{array}$ & $\begin{array}{c}17,2 \% \\
\text { Rzeszów }\end{array}$ & $24,4 \%$ & $\begin{array}{l}19,2 \% \\
\text { leżajski }\end{array}$ & $\begin{array}{l}30,1 \% \\
\text { Krosno }\end{array}$ & $8,9 \%$ & $\begin{array}{c}5,1 \% \\
\text { brzozowski }\end{array}$ & $\begin{array}{c}14,6 \% \\
\text { Przemyśl }\end{array}$ \\
\hline 2008 & $9,2 \%$ & $\begin{array}{l}5,0 \% \\
\text { leski }\end{array}$ & $\begin{array}{c}20,1 \% \\
\text { Rzeszów }\end{array}$ & $24,8 \%$ & $\begin{array}{c}20,5 \% \\
\text { bieszczadzki }\end{array}$ & $\begin{array}{c}30,2 \% \\
\text { ropczycko- } \\
\text { sędziszowski }\end{array}$ & $9,8 \%$ & $\begin{array}{c}5,9 \% \\
\text { brzozowski }\end{array}$ & $\begin{array}{c}15,2 \% \\
\text { mielecki }\end{array}$ \\
\hline 2009 & $10,2 \%$ & $\begin{array}{l}5,6 \% \\
\text { leski }\end{array}$ & $\begin{array}{c}20,9 \% \\
\text { Rzeszów }\end{array}$ & $25,5 \%$ & $\begin{array}{c}21,2 \% \\
\text { lubaczowski }\end{array}$ & $\begin{array}{c}31,7 \% \\
\text { ropczycko- } \\
\text { sędziszowski }\end{array}$ & $10,3 \%$ & $\begin{array}{c}6,6 \% \\
\text { brzozowski }\end{array}$ & $\begin{array}{c}15,1 \% \\
\text { mielecki }\end{array}$ \\
\hline 2010 & $11,7 \%$ & $\begin{array}{l}6,5 \% \\
\text { leski }\end{array}$ & $\begin{array}{c}24,0 \% \\
\text { Rzeszów }\end{array}$ & $25,3 \%$ & $\begin{array}{c}20,7 \% \\
\text { lubaczowski }\end{array}$ & $\begin{array}{c}32,2 \% \\
\text { ropczycko- } \\
\text { sędziszowski }\end{array}$ & $10,4 \%$ & $\begin{array}{c}6,5 \% \\
\text { brzozowski }\end{array}$ & $\begin{array}{c}15,0 \% \\
\text { mielecki }\end{array}$ \\
\hline 2011 & $12,8 \%$ & $\begin{array}{c}7,6 \% \\
\text { bieszczadzki }\end{array}$ & $\begin{array}{c}26,0 \% \\
\text { Rzeszów }\end{array}$ & $25,5 \%$ & $\begin{array}{c}20,5 \% \\
\text { lubaczowski }\end{array}$ & $\begin{array}{c}32,9 \% \\
\text { ropczycko- } \\
\text { sędziszowski }\end{array}$ & $10,5 \%$ & $\begin{array}{c}6,2 \% \\
\text { brzozowski }\end{array}$ & $\begin{array}{c}15,4 \% \\
\text { mielecki }\end{array}$ \\
\hline
\end{tabular}

cd. Tabela 2. Struktura bezrobotnych ze względu na wykształcenie w województwie podkarpackim

\begin{tabular}{|c|c|c|c|c|c|c|}
\hline \multirow{2}{*}{ lata } & \multicolumn{2}{|c|}{ Zasadnicze zawodowe } & \multicolumn{3}{c|}{ Gimnazjalne i poniżej } \\
\cline { 2 - 7 } & $\mathbf{A}$ & $\mathbf{B}$ & $\mathbf{C}$ & $\mathbf{A}$ & $\mathbf{B}$ & $\mathbf{C}$ \\
\hline $\mathbf{2 0 0 3}$ & $38,2 \%$ & $\begin{array}{c}23,5 \% \\
\text { Rzeszów }\end{array}$ & $\begin{array}{c}46,7 \% \\
\text { strzyżowski }\end{array}$ & $26,8 \%$ & $\begin{array}{c}19,7 \% \\
\text { strzyżowski }\end{array}$ & $\begin{array}{c}34,5 \% \\
\text { rzeszowski }\end{array}$ \\
\hline $\mathbf{2 0 0 4}$ & $36,4 \%$ & $\begin{array}{c}22,8 \% \\
\text { Rzeszów }\end{array}$ & $\begin{array}{c}44,9 \% \\
\text { strzyżowski }\end{array}$ & $26,6 \%$ & $\begin{array}{c}20,2 \% \\
\text { strzyżowski }\end{array}$ & $\begin{array}{c}33,1 \% \\
\text { rzeszowski }\end{array}$ \\
\hline $\mathbf{2 0 0 5}$ & $35,2 \%$ & $\begin{array}{c}22,3 \% \\
\text { Rzeszów }\end{array}$ & $\begin{array}{c}44,0 \% \\
\text { strzyżowski }\end{array}$ & $26,2 \%$ & $\begin{array}{c}20,2 \% \\
\text { strzyżowski }\end{array}$ & $\begin{array}{c}32,9 \% \\
\text { rzeszowski }\end{array}$ \\
\hline $\mathbf{2 0 0 6}$ & $33,9 \%$ & $\begin{array}{c}21,1 \% \\
\text { Rzeszów }\end{array}$ & $\begin{array}{c}43,2 \% \\
\text { strzyżowski }\end{array}$ & $26,6 \%$ & $\begin{array}{c}20,3 \% \\
\text { strzyżowski }\end{array}$ & $\begin{array}{c}33,7 \% \\
\text { rzeszowski }\end{array}$ \\
\hline $\mathbf{2 0 0 7}$ & $32,4 \%$ & $\begin{array}{c}19,8 \% \\
\text { Rzeszów }\end{array}$ & $\begin{array}{c}41,4 \% \\
\text { strzyżowski }\end{array}$ & $26,5 \%$ & $\begin{array}{c}19,2 \% \\
\text { strzyżowski }\end{array}$ & $\begin{array}{c}33,6 \% \\
\text { rzeszowski }\end{array}$ \\
\hline $\mathbf{2 0 0 8}$ & $31,9 \%$ & $\begin{array}{c}18,3 \% \\
\text { Rzeszów }\end{array}$ & $\begin{array}{c}40,3 \% \\
\text { strzyżowski }\end{array}$ & $24,4 \%$ & $\begin{array}{c}17,8 \% \\
\text { strzyżowski }\end{array}$ & $\begin{array}{c}30,1 \% \\
\text { rzeszowski }\end{array}$ \\
\hline $\mathbf{2 0 0 9}$ & $31,5 \%$ & $\begin{array}{c}19,5 \% \\
\text { Rzeszów }\end{array}$ & $\begin{array}{c}40,1 \% \\
\text { strzyżowski }\end{array}$ & $22,5 \%$ & $\begin{array}{c}17,2 \% \\
\text { Krosno }\end{array}$ & $\begin{array}{c}27,0 \% \\
\text { bieszczadzki }\end{array}$ \\
\hline $\mathbf{2 0 1 0}$ & $30,9 \%$ & $\begin{array}{c}18,3 \% \\
\text { Rzeszów }\end{array}$ & $\begin{array}{c}39,5 \% \\
\text { strzyżowski }\end{array}$ & $21,8 \%$ & $\begin{array}{c}16,7 \% \\
\text { Krosno }\end{array}$ & $\begin{array}{c}27,4 \% \\
\text { bieszczadzki }\end{array}$ \\
\hline $\mathbf{2 0 1 1}$ & $30,2 \%$ & $\begin{array}{c}18,0 \% \\
\text { Rzeszów }\end{array}$ & $\begin{array}{c}38,2 \% \\
\text { strzyżowski }\end{array}$ & $20,9 \%$ & $\begin{array}{c}14,9 \% \\
\text { Krosno }\end{array}$ & $\begin{array}{c}26,7 \% \\
\text { bieszczadzki }\end{array}$ \\
\hline
\end{tabular}

A - średni udział dla województwa w poszczególnych latach, B - minimalny udział na poziomie powiatów, $\mathrm{C}$ - maksymalny udział na poziomie powiatów

Źródło: obliczenia własne na podstawie danych na stronie www.stat.gov.pl. 
Najwyższy odsetek osób z wyższym wykształceniem odnotowano w powiecie grodzkim Rzeszów (12,6-26\% wszystkich bezrobotnych). Na uwagę zasługuje jednak, że po pierwsze, udział tej grupy bezrobotnych w bezrobotnych ogółem systematycznie rósł i w latach 2003-2011 podwoił się. Po drugie, w stolicy województwa podkarpackiego znajdują się największe w regionie uczelnie wyższe oraz to, że wielu absolwentów pozostaje po skończeniu studiów w Rzeszowie i tu poszukuje pracy, wpływa no to, iż w tym powiecie odnotowano największe udziały tej grupy bezrobotnych. Najmniejszy udział bezrobotnych z wyższym wykształceniem notowano natomiast $\mathrm{w}$ powiatach: brzozowskim $(2,6 \%$ w 2003 r.), bieszczadzkim (2,6-4,1\% w latach 2004-2007 i 7,6\% w 2011 r.) czy leskim (5-6,5\% w okresie 2008-2010). Minimalne udziały tej grupy bezrobotnych w ogólnej liczbie zarejestrowanych pozostających bez pracy $\mathrm{w}$ wymienionych powiatach również systematycznie rosły, ulegając potrojeniu w $2011 \mathrm{r}$. w stosunku do $2003 \mathrm{r}$.

Najwięcej osób z wykształceniem policealnym i średnim zawodowym pozostających bez pracy zarejestrowanych było w Krośnie (około 30\% w latach 2005-2007) oraz w powiecie ropczycko-sędziszowskim (ok. 30-33\% w okresie 2008-2011). Osoby z wykształceniem średnim ogólnokształcącym zarejestrowane jako bezrobotne stanowiły najmniejszy udział w bezrobotnych ogółem w powiecie brzozowskim, największy udział tej grupy bezrobotnych zaś notowano w powiecie Przemyśl oraz mieleckim. Stosunkowo niski udział tej grupy bezrobotnych wynikał przede wszystkim stąd, że większość osób po skończeniu liceum ogólnokształcącego, ze względu na brak wyuczonego zawodu, kontynuowała naukę na wyższych studiach.

W większości powiatów bezrobotni z wykształceniem zasadniczym zawodowym stanowili największy odsetek ogólnej liczby bezrobotnych. Najwyższe udziały tej grupy bezrobotnych notowano w powiecie strzyżowskim, gdzie w 2003 r. prawie połowę (47\%) wszystkich zarejestrowanych pozostających bez pracy stanowili bezrobotni z wykształceniem zasadniczym zawodowym. Najmniejszy udział tej grupy bezrobotnych notowano w Rzeszowie (23,5-18\%). W analizowanym okresie zarówno średnie udziały dla całego województwa, jak i w powiatach, gdzie notowano maksymalne i minimalne udziały grupy bezrobotnych $\mathrm{z}$ wykształceniem zasadniczym zawodowym, systematycznie spadały odpowiednio: o 8 pkt. procentowych (dla średniego udziału w województwie), o 5,5 pkt. procentowego (w Rzeszowie, gdzie notowano minimalne udziały) oraz o 8,5 pkt. procentowego (w powiecie strzyżowskim, gdzie notowano maksymalne udziały).

Bezrobotni z najniższym poziomem wykształcenia (gimnazjalne i poniżej) w województwie podkarpackim stanowili średnio ok. 1/4 wszystkich bezrobotnych. Największy udział tej grupy bezrobotnych notowano w powiecie rzeszowskim ziemskim oraz bieszczadzkim, najmniejsze natomiast $\mathrm{w}$ powiatach strzyżowskim oraz powiece grodzkim Krosno. W przypadku tej grupy bezrobotnych, podobnie jak w grupie bezrobotnych z wykształceniem zasadniczym zawodowych, udziały w grupie bezrobotnych ogółem systematycznie malały.

\subsection{Struktura bezrobocia ze względu na wiek}

Rozpatrując strukturę bezrobotnych ze względu na wiek, dokonano podziału bezrobotnych na dwie grupy: tzw. „młodych bezrobotnych” w wieku do 24 lat włącznie oraz druga grupa bezrobotni 25 lat i powyżej. Taki podział jedynie na dwie kategorie wiekowe wynikał przede wszystkim stąd, że osobom wchodzącym na rynek pracy jest stosunkowo trudniej znaleźć pracę ze względu na brak doświadczenia zawodowego. W dalszych analizach prowadzonych $\mathrm{w}$ punkcie trzecim celem będzie wykazanie, która grupa bezrobot- 
nych tzw. młodych czy z doświadczeniem oraz stażem zawodowym jest bardziej podatna na sytuację koniunkturalną.

Średni udział „młodych bezrobotnych” był dość wysoki i wyniósł ok. 1/4 wszystkich bezrobotnych w województwie, mimo że biorąc pod uwagę wiek produkcyjny w Polsce, ta grupa bezrobotnych stanowi zaledwie ok. 1/7 przedziału wieku produkcyjnego. Jak wynika z danych zestawionych w tabeli 3, w latach 2003-2007, czyli w okresie dobrej koniunktury, kiedy stopy bezrobocia ogółem się zmniejszały, udział młodych bezrobotnych również systematycznie malał z poziomu $28 \%$ w 2003 r. do 21,5\% w 2007, po czym znów zaczął wzrastać, osiagając w 2011 r. niecałe 24\% ogólnej liczby bezrobotnych w województwie.

Tabela 3. Struktura bezrobotnych ze względu na wiek w województwie podkarpackim

\begin{tabular}{|c|c|c|c|c|c|c|}
\hline \multirow{2}{*}{ Lata } & \multicolumn{2}{|c|}{$\mathbf{2 4}$ lata i poniżej } & \multicolumn{3}{c|}{ 25 lat i powyżej } \\
\cline { 2 - 7 } & $\mathbf{A}$ & $\mathbf{B}$ & $\mathbf{C}$ & $\mathbf{A}$ & $\mathbf{B}$ & $\mathbf{C}$ \\
\hline $\mathbf{2 0 0 3}$ & $28,0 \%$ & $\begin{array}{c}20,5 \% \\
\text { Rzeszów }\end{array}$ & $\begin{array}{c}33,3 \% \\
\text { przeworski }\end{array}$ & $72,0 \%$ & $\begin{array}{c}66,7 \% \\
\text { przeworski }\end{array}$ & $\begin{array}{c}79,5 \% \\
\text { Rzeszów }\end{array}$ \\
\hline $\mathbf{2 0 0 4}$ & $26,3 \%$ & $\begin{array}{c}18,9 \% \\
\text { Rzeszów }\end{array}$ & $\begin{array}{c}32,5 \% \\
\text { przeworski }\end{array}$ & $73,7 \%$ & $\begin{array}{c}67,5 \% \\
\text { przeworski }\end{array}$ & $\begin{array}{c}81,1 \% \\
\text { Rzeszów }\end{array}$ \\
\hline $\mathbf{2 0 0 5}$ & $25,0 \%$ & $\begin{array}{c}18,4 \% \\
\text { Rzeszów }\end{array}$ & $\begin{array}{c}30,8 \% \\
\text { przemyski }\end{array}$ & $75,0 \%$ & $\begin{array}{c}69,2 \% \\
\text { przemyski }\end{array}$ & $\begin{array}{c}81,6 \% \\
\text { Rzeszów }\end{array}$ \\
\hline $\mathbf{2 0 0 6}$ & $23,0 \%$ & $\begin{array}{c}15,7 \% \\
\text { Rzeszów }\end{array}$ & $\begin{array}{c}27,8 \% \\
\text { przeworski }\end{array}$ & $77,0 \%$ & $\begin{array}{c}72,2 \% \\
\text { przeworski }\end{array}$ & $\begin{array}{c}84,3 \% \\
\text { Rzeszów }\end{array}$ \\
\hline $\mathbf{2 0 0 7}$ & $21,5 \%$ & $\begin{array}{c}15,1 \% \\
\text { Krosno }\end{array}$ & $\begin{array}{c}26,0 \% \\
\text { przemyski }\end{array}$ & $78,5 \%$ & $\begin{array}{c}74,0 \% \\
\text { przemyski }\end{array}$ & $\begin{array}{c}84,9 \% \\
\text { Krosno }\end{array}$ \\
\hline $\mathbf{2 0 0 8}$ & $22,7 \%$ & $\begin{array}{c}16,2 \% \\
\text { Przemyśl }\end{array}$ & $\begin{array}{c}29,5 \% \\
\text { dębicki }\end{array}$ & $77,3 \%$ & $\begin{array}{c}70,5 \% \\
\text { dębicki }\end{array}$ & $\begin{array}{c}83,8 \% \\
\text { Przemyśl }\end{array}$ \\
\hline $\mathbf{2 0 0 9}$ & $25,3 \%$ & $\begin{array}{c}16,9 \% \\
\text { Przemyśl }\end{array}$ & $\begin{array}{c}31,7 \% \\
\text { dębicki }\end{array}$ & $74,7 \%$ & $\begin{array}{c}68,3 \% \\
\text { dębicki }\end{array}$ & $\begin{array}{c}83,1 \% \\
\text { Przemyśl }\end{array}$ \\
\hline $\mathbf{2 0 1 0}$ & $24,5 \%$ & $\begin{array}{c}16,2 \% \\
\text { Przemyśl }\end{array}$ & $\begin{array}{c}30,0 \% \\
\text { ropczycko-sędziszowski }\end{array}$ & $75,5 \%$ & $\begin{array}{c}70,0 \% \\
\text { ropczycko-sędziszowski }\end{array}$ & $\begin{array}{c}83,8 \% \\
\text { Przemyśl }\end{array}$ \\
\hline $\mathbf{2 0 1 1}$ & $23,8 \%$ & $\begin{array}{c}13,9 \% \\
\text { Przemyśl }\end{array}$ & $\begin{array}{c}31,7 \% \\
\text { ropczycko-sędziszowski }\end{array}$ & $76,2 \%$ & $\begin{array}{r}68,3 \% \\
\text { ropczycko-sędziszowski }\end{array}$ & $\begin{array}{c}86,1 \% \\
\text { Przemyśl }\end{array}$ \\
\hline
\end{tabular}

A - średni udział dla województwa w poszczególnych latach, B - minimalny udział na poziomie powiatów, $\mathrm{C}$ - maksymalny udział na poziomie powiatów

Źródło: obliczenia własne na podstawie danych na stronie www.stat.gov.pl.

Grupa ta, podobnie jak pozostałe rozważane grupy bezrobotnych, charakteryzowała się zróżnicowanymi udziałami na poziomie powiatów. Najniższe udziały tej grupy notowano w powiatach grodzkich Rzeszów (20,5\% do 15,7\% w latach 2003-2006), Krosno (15,1\% w 2007 r.) oraz Przemyśl (16,2\% do 13,9\% w okresie 2008-2011). 
Rys. 3. Udział bezrobotnych według wieku w województwie podkarpackim

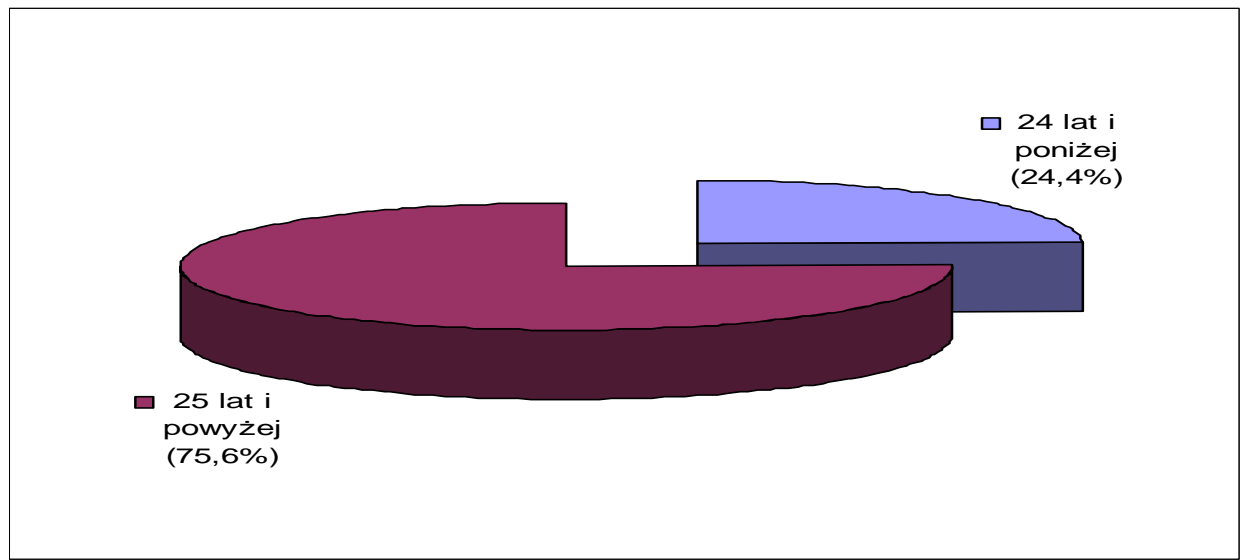

Źródło: opracowanie własne na podstawie danych w tabeli 3.

Najwyższe udziały „młodych bezrobotnych” w ogólnej liczbie bezrobotnych cechowały takie powiaty, jak przeworski, gdzie w latach 2003-2003 ta grupa bezrobotnych stanowiła około 1/3 bezrobotnych ogółem. Wysokimi udziałami tej grupy charakteryzowały się powiaty: przemyski, dębicki oraz ropczycko-sędziszowski. Udziały (średnie, maksymalne i minimalne) tej grupy bezrobotnych spadały w okresie dobrej koniunktury gospodarczej (2003-2008), a rosły w czasie spowolnienia gospodarczego po 2008 r. Może to zatem oznaczać, że ta grupa bezrobotnych wykazuje wyższy poziom koniunkturalności niż grupa 25 lat i powyżej.

\subsection{Struktura bezrobocia według miejsca zamieszkania}

$\mathrm{Z}$ danych zestawionych $\mathrm{w}$ tabeli 4 wynika, że prawie $2 / 3$ wszystkich bezrobotnych w województwie podkarpackim to mieszkańcy obszarów wiejskich, niewiele ponad 1/3 bezrobotnych w analizowanym okresie mieszkała w mieście.

Najniższy udział bezrobotnych zamieszkałych na wsi notowano w powiecie stalowowolskim. Najwyższym udziałem tej grupy bezrobotnych charakteryzował się powiat przemyski ziemski, gdzie wszyscy bezrobotni to mieszkańcy obszarów wiejskich, co wynika przede wszystkim z tego, że powiat ten składa się w całości z 10 gmin wiejskich. 
Tabela 4. Struktura bezrobotnych ze względu na miejsce zamieszkania w woj. podkarpackim

\begin{tabular}{|c|c|c|c|c|c|c|}
\hline \multirow{2}{*}{ Lata } & \multicolumn{3}{|c|}{ Zamieszkali na wsi } & \multicolumn{3}{|c|}{ Zamieszkali w mieście } \\
\hline & $\mathbf{A}$ & B & $\mathbf{C}$ & $\mathbf{A}$ & $\mathbf{B}^{*}$ & $\mathbf{C}^{* *}$ \\
\hline 2003 & $63,1 \%$ & $\begin{array}{c}43,4 \% \\
\text { stalowowolski }\end{array}$ & \multirow{9}{*}{ przemyski } & $36,9 \%$ & $\begin{array}{c}9,5 \% \\
\text { brzozowski }\end{array}$ & $\begin{array}{c}56,6 \% \\
\text { stalowowolski }\end{array}$ \\
\hline 2004 & $63,4 \%$ & $\begin{array}{c}43,4 \% \\
\text { stalowowolski }\end{array}$ & & $36,6 \%$ & $\begin{array}{c}9,4 \% \\
\text { brzozowski }\end{array}$ & $\begin{array}{c}56,6 \% \\
\text { stalowowolski }\end{array}$ \\
\hline 2005 & $63,3 \%$ & $\begin{array}{c}48,3 \% \\
\text { stalowowolski }\end{array}$ & & $36,7 \%$ & $\begin{array}{c}9,3 \% \\
\text { brzozowski }\end{array}$ & $\begin{array}{c}51,7 \% \\
\text { stalowowolski }\end{array}$ \\
\hline 2006 & $63,4 \%$ & $\begin{array}{c}52,3 \% \\
\text { stalowowolski }\end{array}$ & & $36,6 \%$ & $\begin{array}{c}8,8 \% \\
\text { brzozowski }\end{array}$ & $\begin{array}{c}47,7 \% \\
\text { stalowowolski }\end{array}$ \\
\hline 2007 & $63,2 \%$ & $\begin{array}{c}40,4 \% \\
\text { stalowowolski }\end{array}$ & & $36,8 \%$ & $\begin{array}{c}9,2 \% \\
\text { brzozowski }\end{array}$ & $\begin{array}{c}59,6 \% \\
\text { stalowowolski }\end{array}$ \\
\hline 2008 & $62,8 \%$ & $\begin{array}{c}26,7 \% \\
\text { stalowowolski }\end{array}$ & & $37,2 \%$ & $\begin{array}{c}8,4 \% \\
\text { brzozowski }\end{array}$ & $\begin{array}{c}73,3 \% \\
\text { stalowowolski }\end{array}$ \\
\hline 2009 & $62,5 \%$ & $\begin{array}{c}43,5 \% \\
\text { stalowowolski }\end{array}$ & & $37,5 \%$ & $\begin{array}{c}8,7 \% \\
\text { brzozowski }\end{array}$ & $\begin{array}{c}56,5 \% \\
\text { stalowowolski }\end{array}$ \\
\hline 2010 & $62,3 \%$ & $\begin{array}{c}42,4 \% \\
\text { stalowowolski }\end{array}$ & & $37,7 \%$ & $\begin{array}{c}9,2 \% \\
\text { brzozowski }\end{array}$ & $\begin{array}{c}57,6 \% \\
\text { stalowowolski }\end{array}$ \\
\hline 2011 & $62,4 \%$ & $\begin{array}{c}42,9 \% \\
\text { stalowowolski }\end{array}$ & & $37,6 \%$ & $\begin{array}{c}9,3 \% \\
\text { brzozowski }\end{array}$ & $\begin{array}{c}57,1 \% \\
\text { stalowowolski }\end{array}$ \\
\hline
\end{tabular}

A - średni udział dla województwa w poszczególnych latach, B - minimalny udział na poziomie powiatów, $\mathrm{C}$ - maksymalny udział na poziomie powiatów; $\mathrm{B}^{*}$ wartość obliczona $\mathrm{z}$ pominięciem powiatu przemyskiego, który składa się z samych gmin wiejskich, co powoduje, że bezrobotnych zamieszkałych $\mathrm{w}$ mieście nie wykazano; $\mathrm{C}^{* *}$ maksymalne wartości udziałów podano $\mathrm{z}$ pominięciem powiatów Krosno, Przemyśl, Rzeszów oraz Tarnobrzeg, gdzie w tych powiatach $100 \%$ bezrobotnych zamieszkałych jest w mieście.

Źródło: obliczenia własne na podstawie danych na stronie www.stat.gov.pl.

Spośród bezrobotnych zamieszkałych w mieście minimalny udział notowano w powiecie brzozowskim, gdzie zaledwie ok. 8,5-9,5\% to bezrobotni mieszkający w mieście. Natomiast najwyższym odsetkiem bezrobotnych mieszkających w mieście (oprócz powiatów grodzkich, gdzie $100 \%$ bezrobotnych to mieszkańcy miasta) charakteryzował się powiat stalowowolski.

\section{ZALEŻNOŚĆ MIĘDZY RYNKIEM TOWAROWYM A BEZROBOCIEM - UJECCIE TEORETYCZNE}

Jak wynika z przeglądu licznych badań, jedną z głównych determinant zatrudnienia, a jednocześnie bezrobocia są zmiany w dynamice produktu krajowego brutto (PKB) ${ }^{2}$. Analizując zależności wynikające $\mathrm{z}$ interakcji pomiędzy rynkiem pracy oraz rynkiem towarowym, można dojść do wniosku, że popyt na pracę jest popytem pochodnym i w dużej mierze zależy od sytuacji na rynku towarowym. Na ten aspekt uwagę zwracał już sam Keynes, który przyczyn występowania bezrobocia przymusowego szukał nie na samym

\footnotetext{
${ }^{2}$ A.B. Czyżewski, Wzrost gospodarczy a popyt na prace, „Bank i Kredyt” 2002/11-12; E. Kwiatkowski, L. Kucharski, T. Tokarski, Bezrobocie i zatrudnienie a PKB w Polsce w latach 1993-2001, „Ekonomista” 2002/3; E. Kwiatkowski, Kryzys globalny a rynek pracy w Polsce i innych krajach Grupy Wyszehradziej, „Ekonomista” 2011/1; A. Rogut, Determinanty popytu na prace w Polsce w okresie transformacji, Wydawnictwo Uniwersytetu Łódzkiego, Łódź 2008; J. Socha, Tworzenie i likwidacja miejsc pracy w sektorze przedsiębiorstw w Polsce, „Gospodarka Narodowa” 2006/5-6; M. Socha, U. Sztanderska, Strukturalne podstawy bezrobocia w Polsce, Wydawnictwo Naukowe PWN, Warszawa 2000; A. Ziomek, Produkt krajowy a bezrobocie, Wydawnictwo Wyższej Szkoły Bankowej, Poznań 2006.
} 
rynku pracy, ale na rynku towarowym. Interpretacja teorii Keynesa wskazuje na związek między produkcją (wytworzonym PKB wynikającym z kształtowania się popytu globalnego) a popytem na pracę. W ujęciu tradycyjnym popyt na pracę jest zatem funkcją globalnego popytu. Natomiast analizując model wzrostu gospodarczego Harroda-Dommara, można dojść do wniosku, że popyt na pracę jest rosnącą funkcją produkcji (PKB) i malejącą funkcją wydajności pracy. Innymi słowy, popyt na pracę rośnie, jeśli produkcja rośnie szybciej od wydajności pracy ${ }^{3}$. Wynika stąd zatem, że jeżeli istnieje odwrotna zależność między popytem na pracę a wielkością bezrobocia, to wówczas, gdy rośnie (maleje) wielkość produkcji, to maleje (rośnie) stopa bezrobocia ${ }^{4}$.

Istnieją jednak dowody na to, że zmiany w popycie na pracę (zatrudnienie), a jednocześnie i w bezrobociu są słabsze niż w produkcji i występują z pewnym opóźnieniem. Zgodnie z prawem Okuna zmiany w bezrobociu mogą być relatywnie mniejsze niż w produkcji, ponieważ pracodawcy dostosowują nie tylko wielkość zatrudnienia, ale i czas pracy oraz godzą się na spadek wydajności pracy podczas okresu złej koniunktury. Można zaobserwować takie zjawisko, jak chomikowanie pracy (labour hoarding) polegające na zatrzymywaniu części pracowników w okresach dekoniunktury ${ }^{5}$. Głównymi determinantami takiego zachowania pracodawców są koszty związane z rotacją pracowników, ze zwalnianiem, a następnie zatrudnianiem w czasie poprawy koniunktury (wydatki na odprawy i rekrutację, na szkolenia nowych pracowników). W rezultacie w okresie spowolnienia gospodarczego redukcje zatrudnienia (wzrosty stóp bezrobocia) mogą być mniejsze niż spadki produkcji, w okresie ożywienia zaś wzrosty produkcji są większe niż wzrost zatrudnienia (większe niż spadki bezrobocia). Oprócz tego zmiany w zatrudnieniu następują $\mathrm{z}$ pewnym opóźnieniem $\mathrm{w}$ stosunku do zmian $\mathrm{w}$ produkcji, ponieważ pracodawcy najpierw dostosowują czas pracy, a dopiero później zatrudnienie, co powoduje, że stopy bezrobocia też spadają z pewnym opóźnieniem ${ }^{6}$.

Na podstawie tych rozważań przyrosty stóp bezrobocia rejestrowanego na poziomie powiatów można uzależnić od poziomu powiatowych stóp bezrobocia rejestrowanego oraz stopy wzrostu produkcji. W tym celu można posłużyć się definicją stopy bezrobo$\operatorname{cia}^{7}$ :

$$
u_{i}(t)=\frac{U_{i}(t)}{U_{i}(t)+L_{i}(t)}=1-\frac{L_{i}(t)}{N_{i}(t)},
$$

gdzie $u_{i}(t)$ oznacza stopę bezrobocia w powiecie $i$ w momencie $t, U_{i}(t)$ - liczbę bezrobotnych w powiecie $i$ w momencie $t, L_{i}(t)$ - liczbę pracujących, $N_{i}(t)$ zaś - podaż pracy.

\footnotetext{
${ }^{3}$ A. Rogut, op. cit., s. 53-57, 62-65; T. Tokarski, P. Gajewski, Zależność między wydajnościq pracy i zatrudnieniem w krajach OECD, „Wiadomości Statystyczne” 2002/8, s. 59-60, lub np. K. Bartosik, Popyt na pracę w Polsce w warunkach spowolnienia gospodarczego, ,Studia Ekonomiczne” LXX/3 (2011).

${ }^{4}$ Zależność taka zachodzi, jeżeli wzrost produkcji ma charakter zatrudnieniowy. Wzrost produkcji może być bowiem efektem wzrostu wydajności pracy. Wówczas taki wzrost produkcji ma charakter bezzatrudnieniowy.

${ }^{5}$ Przykładem chomikowania pracy może być WSK Rzeszów, który w latach 2008-2009 oprócz zwolnień również chomikował pracowników kosztem spadku wydajności pracy, stosując np. czterodniowy tydzień pracy.

${ }^{6}$ Por. np. K. Bartosik, op. cit.

${ }^{7} \mathrm{O}$ wszystkich występujących w punkcie 3 zmiennych zakłada się, że są różniczkowalnymi funkcjami czasu $t \in[0 ;+\infty)$. Zapis $\dot{x}(t)=d x / d t$ będzie oznaczał pochodną zmiennej $x$ po czasie $t$, czyli - ekonomicznie rzecz biorąc - przyrost wartości owej zmiennej w momencie $t$.
} 
Różniczkując równanie (1) względem czasu $t$, otrzymuje się przyrost stopy bezrobocia dany wzorem:

$$
\dot{u}_{i}(t)=-\frac{\dot{L}_{i}(t) N_{i}(t)-L_{i}(t) \dot{N}_{i}(t)}{\left(N_{i}(t)\right)^{2}}=\frac{L_{i}(t)}{N_{i}(t)}\left[\frac{\dot{N}_{i}(t)}{N_{i}(t)}-\frac{\dot{L}_{i}(t)}{L_{i}(t)}\right],
$$

a stąd oraz z równania (1) wynika, że przyrost stopy bezrobocia można zapisać następująco:

$$
\dot{u}_{i}(t)=\left(1-u_{i}(t)\right)\left(\frac{\dot{N}_{i}(t)}{N_{i}(t)}-\frac{\dot{L}_{i}(t)}{L_{i}(t)}\right)
$$

Następnie zakładając, że stopa wzrostu liczby pracujących $\frac{\dot{L}_{i}(t)}{L_{i}(t)}$ jest rosnącą funkcją stopy wzrostu produkcji $g_{i}$, okazuje się, że przyrost stopy bezrobocia dany jest zależnością:

$$
\dot{u}_{i}(t)=\left(1-u_{i}(t)\right)\left[\frac{\dot{N}_{i}(t)}{N_{i}(t)}-f\left(g_{i}\right)\right]
$$

gdzie $\frac{\dot{L}_{i}(t)}{L_{i}(t)}=f\left(g_{i}\right)$, przy czym $\frac{d f}{d g_{i}}>0$. Z równania (3) wynika, że przyrost stopy bezrobocia jest malejącą funkcją stopy wzrostu produktu $g_{i}$ oraz jeżeli stopa wzrostu podaży pracy jest większa (mniejsza) od stopy wzrostu liczby pracujących, to przyrost stopy bezrobocia jest malejącą (rosnąca) funkcją stopy bezrobocia.

\section{WYNIKI ANALIZ STATYSTYCZNYCH}

Biorąc pod uwagę determinanty zmiany stóp bezrobocia wynikające z rozważań teoretycznych (punkt 2) oraz zależności wynikające ze wzoru (3), można oszacować parametry następującego równania opisującego przyrosty stóp bezrobocia ${ }^{8}$ :

$$
\Delta u_{i t}=\alpha_{0}-\alpha_{1} u_{i t-1}+\alpha_{2} d_{\Delta u} u_{i t-1}-\alpha_{3} \Delta \ln \left(P K B_{i t}\right)
$$

gdzie:

$u_{i t}=\frac{U_{i t}}{U_{i t}+L_{i t}}-$ stopa bezrobocia rejestrowanego $\mathrm{w} i$-tym powiatowym rynku pracy $\mathrm{w}$ roku $t$;

$\Delta \ln \left(P K B_{i t}\right)-$ stopa wzrostu PKB;

$\alpha_{0}$ - stała rzeczywista określająca wzrost stopy bezrobocia, który wystąpiłby przy zerowej stopie bezrobocia w poprzednim okresie oraz przy zerowej stopie wzrostu PKB;

\footnotetext{
${ }^{8}$ Równanie to w wersji zmodyfikowanej wykorzystano np. w pracy T. Misiak, T. Tokarski, Wzrost PKB a zmiany zatrudnienia i bezrobocia w krajach Unii Europejskiej, „Folia Oeconomica” 2011/248.
} 
$\alpha_{1}$ - zmienna, która mierzy siłę oddziaływania stopy bezrobocia w sytuacji, gdy owa zmienna nie rośnie;

$\alpha_{2}$ - mierzy siłę wpływu stopy bezrobocia na wzrost tej stopy w sytuacji, gdy stopa bezrobocia rośnie;

$\alpha_{3}$ - opisuje zależność przyrostu stopy bezrobocia rejestrowanego od stopy wzrostu $\mathrm{PKB}$;

$d_{\Delta u}$ - zmienna zerojedynkowa, która przyjmuje wartość 1, gdy stopa bezrobocia rejestrowanego rośnie, w przeciwnym wypadku zaś - 0 .

Interpretacja parametrów $\alpha_{1}$ i $\alpha_{2}$ wynika stąd, że zmienna zerojedynkowa $d_{\Delta u}$ w równaniu zmiany stóp bezrobocia pełni funkcję zmiennej przełącznikowej korygującej oddziaływanie stopy bezrobocia z poprzedniego okresu na zmianę bieżącej stopy bezrobocia i zależy od tego, czy przyrost tej stopy jest dodatni, czy ujemny.

Równanie (4) można zatem próbować zastosować, biorąc pod uwagę kształtowanie się struktury bezrobocia. Należałoby w tym celu zamiast przyrostu stóp bezrobocia ogółem w równaniu (4) uwzględnić np. przyrosty stóp bezrobocia kobiet, mężczyzn czy też np. stopy bezrobocia wśród osób z wyższym wykształceniem itd. Pozwoliłoby to na ustalenie, na jaką grupę bezrobotnych zmiany koniunkturalne na rynku towarowym mają największy (najmniejszy) wpływ. Jednakże ze względu na fakt, że Główny Urząd Statystyczny (GUS) nie publikuje danych dotyczących kształtowania się stóp bezrobocia na poziomie powiatowym w ujęciu struktury bezrobotnych ani też nie podaje co do struktury poziomu aktywnych zawodowo obliczeń stóp bezrobocia wśród np. kobiet, mężczyzn czy też zamieszkałych $\mathrm{w}$ mieście lub stopy bezrobocia na poziomie powiatowym osób z wyższym wykształceniem, staje się to niemożliwe z powodu braku odpowiednich danych. $\mathrm{Z}$ tego względu równanie (4) zmodyfikowano do postaci:

$$
\Delta \ln U_{j i t}=\alpha_{0}-\alpha_{1} \ln U_{j i t-1}+\alpha_{2} d_{\Delta u} \ln U_{j i t-1}-\alpha_{3} \Delta \ln \left(Y_{i t}\right)
$$

gdzie:

$U_{j_{i t}}$ - poziom j-tej grupy bezrobotnych zarejestrowanych w $i$-tym powiatowym rynku pracy w roku $t$;

$\Delta \ln \left(Y_{i t}\right)$ - stopa wzrostu produkcji mierzona wielkością produkcji sprzedanej przemysłu w i-tym powiecie $\mathrm{w}$ roku $\mathrm{t}^{9}$;

$\alpha_{0}$ - stała określająca zmianę stopy wzrostu j-tej grupy bezrobotnych, który wystąpiłby przy zerowym poziomie tej grupy bezrobotnych w poprzednim okresie oraz przy zerowej stopie wzrostu produkcji;

\footnotetext{
${ }^{9}$ Lepszym miernikiem do tego typu analiz jest wielkość PKB, jednakże tych danych GUS również nie szacuje na poziomie powiatów. $Z$ tego powodu najodpowiedniejszą zmienną makroekonomiczną publikowaną przez GUS jest produkcja sprzedana przemysłu brutto.
} 
$\alpha_{1}$ - zmienna, która mierzy siłę oddziaływania j-tej grupy bezrobotnych w sytuacji, gdy owa zmienna nie rośnie;

$\alpha_{2}$ - mierzy siłę wpływu j-tej grupy bezrobotnych na wzrost tej stopy w sytuacji, gdy poziom bezrobocia w tej grupie rośnie;

$\alpha_{3}$ - elastyczność j-tej grupy bezrobotnych względem produkcji sprzedanej przemysłu brutto;

$d_{\Delta u}$ - zmienna zerojedynkowa, która przyjmuje wartość 1 , gdy poziom bezrobocia rejestrowanego rośnie, w przeciwnym wypadku zaś - 0 .

Interpretacja parametrów $\alpha_{1}$ i $\alpha_{2}$ wynika stąd, że zmienna zerojedynkowa $d_{\Delta u}$ również w równaniu (5) odgrywa rolę zmiennej przełącznikowej korygującej oddziaływanie poziomu j-tej grupy bezrobotnych $\mathrm{z}$ poprzedniego okresu na zmianę bieżącej j-tej grupy bezrobotnych i zależy od tego, czy zmiana jest dodatnia, czy ujemna.

Analizując natomiast w równaniu (5) wpływ przeszłych poziomów bezrobocia oraz stopy wzrostu produkcji na zmiany stopy wzrostu bezrobocia, można dojść do wniosku, że gdyby założyć występowanie zarówno zerowej stopy wzrostu produkcji, jak i zerowy poziom bezrobocia w poprzednim okresie, to okazałoby się, że we wszystkich powiatach wystapiłaby taka sama stopa wzrostu bezrobotnych. Założenie to wydaje się zbyt restrykcyjne. $\mathrm{Z}$ tego powodu równanie (5) rozszerzono, stosując procedurę uzmienniania stałej (fixed effect $)^{10}$. Zatem równie (5) można rozszerzyć do postaci:

$\Delta \ln U_{j i t}=\alpha_{0}+\sum_{j=2}^{25} \phi_{k} d_{k}-\alpha_{1} \ln U_{j i t-1}+\alpha_{2} d_{\Delta u} \ln U_{j i t-1}-\alpha_{3} \Delta \ln \left(Y_{i t}\right)$

gdzie:

$d_{k}$ - to zmienna zerojedynkowa dla każdego k-tego powiatu niebazowego;

$\alpha_{0}$ - stała rzeczywista określająca stopę wzrostu j-tej grupy bezrobotnych, który wystąpiłby przy zerowym poziomie bezrobocia w poprzednim okresie oraz przy zerowej stopie wzrostu produkcji;

$\phi_{k}$ - określa, o ile różniłby się przyrost stopy wzrostu poziomu bezrobocia w powiecie $k$ tym od powiatu bazowego, gdyby wystapiły takie same wartości analizowanych zmiennych jak w powiecie bazowym.

Pozostałe parametry równania (6) interpretuje się analogicznie jak w równaniu (5).

Wyniki estymacji równania (6) metodą MNK dla danych panelowych (pooled OLS) zestawiono w tabeli 5.

\footnotetext{
${ }^{10}$ Szerzej na temat procedury uzmienniania stałej (fixed effect) patrz np. R.S. Pindyck, D.L. Rubinfeld, Econometric Models and Economic Forecast, McGraw-Hills, New York 1991.
} 
Tabela 5. Wyniki estymacji równania (6) dla poszczególnych grup bezrobotnych zarejestrowanych w województwie podkarpackim w latach 2003-2011

\begin{tabular}{|c|c|c|c|c|c|}
\hline \multirow{2}{*}{$\begin{array}{l}\text { Zmienna objaśniana } \\
\text { Stopa wzrostu } \\
\text { bezrobotnych }\end{array}$} & \multicolumn{4}{|c|}{ Zmienne objaśniające } & \multirow[b]{2}{*}{$\begin{array}{c}\mathbf{R}^{2} \\
\text { Skor, } \mathbf{R}^{2} \\
\end{array}$} \\
\hline & Stała & $\ln u_{i t-1}$ & $d_{\Delta} \ln u_{i t^{-1}}$ & $\Delta \ln Y_{i t}$ & \\
\hline Ogółem & $\begin{array}{c}0,1052 \\
(0,0048)\end{array}$ & $\begin{array}{c}-0,1036 \\
(0,0026)\end{array}$ & $\begin{array}{c}0,0191 \\
(0,0000)\end{array}$ & $\begin{array}{c}-0,1403 \\
0,0004\end{array}$ & $\begin{array}{l}0,63 \\
0,58\end{array}$ \\
\hline Mężczyzn & $\begin{array}{c}1,2254 \\
(0,0020)\end{array}$ & $\begin{array}{l}-0,1600 \\
(0,0008)\end{array}$ & $\begin{array}{c}0,0295 \\
(0,0000)\end{array}$ & $\begin{array}{l}-0,2554 \\
(0,0000)\end{array}$ & $\begin{array}{l}0,64 \\
0,58\end{array}$ \\
\hline Kobiet & $\begin{array}{c}0,4424 \\
(0,1653)\end{array}$ & $\begin{array}{l}-0,0624 \\
(0,0995)\end{array}$ & $\begin{array}{c}0,017 \\
(0,0000)\end{array}$ & $\begin{array}{l}-0,0569 \\
(0,0476)\end{array}$ & $\begin{array}{l}0,65 \\
0,60\end{array}$ \\
\hline $\begin{array}{l}\text { Wykształcenie } \\
\text { wyższe }\end{array}$ & $\begin{array}{l}-0,2550 \\
(0,2284)\end{array}$ & $\begin{array}{c}0,0213 \\
(0,4692)\end{array}$ & $\begin{array}{c}0,0361 \\
(0,0000)\end{array}$ & $\begin{array}{l}-0,2467 \\
(0,0000)\end{array}$ & $\begin{array}{l}0,58 \\
0,51\end{array}$ \\
\hline $\begin{array}{l}\text { Wykształcenie poli- } \\
\text { cealne i średnie } \\
\text { zawodowe }\end{array}$ & $\begin{array}{c}1,3263 \\
(0,0001)\end{array}$ & $\begin{array}{l}-0,1840 \\
(0,0001)\end{array}$ & $\begin{array}{c}0,0239 \\
(0,0000)\end{array}$ & $\begin{array}{l}-0,1228 \\
(0,0042)\end{array}$ & $\begin{array}{l}0,63 \\
0,58\end{array}$ \\
\hline $\begin{array}{l}\text { Wykształcenie śred- } \\
\text { nie ogólnokształcace }\end{array}$ & $\begin{array}{c}1,1380 \\
(0,0001)\end{array}$ & $\begin{array}{l}-0,1809 \\
(0,0000)\end{array}$ & $\begin{array}{c}0,0291 \\
(0,0000)\end{array}$ & $\begin{array}{l}-0,1495 \\
(0,0001)\end{array}$ & $\begin{array}{l}0,67 \\
0,62\end{array}$ \\
\hline $\begin{array}{l}\text { Wykształcenie zasad- } \\
\text { nicze zawodowe }\end{array}$ & $\begin{array}{c}0,6960 \\
(0,0116)\end{array}$ & $\begin{array}{l}-0,1082 \\
(0,0032)\end{array}$ & $\begin{array}{c}0,0255 \\
(0,0000)\end{array}$ & $\begin{array}{l}-0,1506 \\
(0,0007)\end{array}$ & $\begin{array}{l}0,62 \\
0,56\end{array}$ \\
\hline $\begin{array}{l}\text { Wykształcenie gim- } \\
\text { nazjalne i poniżej }\end{array}$ & $\begin{array}{l}0,4979 \\
0,0505\end{array}$ & $\begin{array}{l}-0,0784 \\
(0,0174)\end{array}$ & $\begin{array}{c}0,0245 \\
(0,0000)\end{array}$ & $\begin{array}{l}-0,0444 \\
(0,2793)\end{array}$ & $\begin{array}{l}0,54 \\
0,48\end{array}$ \\
\hline Wiek 24 lata i poniżej & $\begin{array}{c}1,0354 \\
(0,0007)\end{array}$ & $\begin{array}{l}-0,1564 \\
(0,0002)\end{array}$ & $\begin{array}{c}0,0353 \\
(0,0000)\end{array}$ & $\begin{array}{l}-0,2233 \\
(0,0000)\end{array}$ & $\begin{array}{l}0,69 \\
0,64\end{array}$ \\
\hline Wiek 25 lat i więcej & $\begin{array}{c}1,0707 \\
(0,0039)\end{array}$ & $\begin{array}{l}-0,1282 \\
(0,0023)\end{array}$ & $\begin{array}{l}0,01795 \\
(0,0000)\end{array}$ & $\begin{array}{l}-0,1202 \\
(0,0007)\end{array}$ & $\begin{array}{l}0,64 \\
0,58\end{array}$ \\
\hline Zamieszkali na wsi & $\begin{array}{c}0,0036 \\
(0,8927)\end{array}$ & $\begin{array}{l}-0,1315 \\
(0,0023)\end{array}$ & $\begin{array}{l}0,01976 \\
(0,0000)\end{array}$ & $\begin{array}{l}-0,1071 \\
(0,0039)\end{array}$ & $\begin{array}{l}0,62 \\
0,56\end{array}$ \\
\hline $\begin{array}{l}\text { Zamieszkali } \\
\text { w mieście }\end{array}$ & $\begin{array}{c}1,1243 \\
(0,0049)\end{array}$ & $\begin{array}{l}-0,1345 \\
(0,0023)\end{array}$ & $\begin{array}{c}0,0240 \\
(0,0000)\end{array}$ & $\begin{array}{l}-0,1324 \\
(0,0014)\end{array}$ & $\begin{array}{l}0,64 \\
0,58\end{array}$ \\
\hline Liczba obserwacji & & & 200 & & \\
\hline Próba & & & $2003-2011$ & & \\
\hline Powiat bazowy & & & Rzeszów & & \\
\hline
\end{tabular}

Źródło: obliczenia własne na podstawie danych na stronie www.stat.gov.pl.

Na podstawie oszacowanych parametrów równania (6) zestawionych w tabeli 5 można wyciągnąć następujące wnioski:

- Wśród wszystkich bezrobotnych zarejestrowanych w województwie podkarpackim zmienność stopy wzrostu bezrobotnych była objaśniana przez zmienność poziomu tego bezrobocia odnotowanego w poprzednich okresach oraz przez stopy wzrostu produkcji sprzedanej przemysłu w około 58\%. Analizując natomiast wyniki estymacji dla poszczególnych grup bezrobotnych, można zauważyć, że skorygowany współczynnik determinacji nieco odbiegał od poziomu dla bezrobotnych ogółem i kształtował się w przedziale 0,48 (dla grupy bezrobotnych z wykształceniem gimnazjalnym i poniżej) do 0,64 (dla grupy bezrobotnych w wieku 24 lat i poniżej).

- Analizując wyniki estymacji uzyskane dla bezrobotnych kobiet i mężczyzn, stwierdzono, że w warunkach nierosnącego bezrobocia każdy kolejny spadek poziomu bezrobocia o $1 \% \mathrm{w}$ poprzednim okresie powodowałby spadek tempa wzrostu bieżącej liczby bezrobotnych o 0,16 punktu procentowego wśród mężczyzn oraz o 0,06 punktu procentowego wśród kobiet. Uzyskany parametr wśród mężczyzn był o ok. 2,5-krotnie wyższy 
niż wśród kobiet. Natomiast w warunkach rosnącego bezrobocia poziom bezrobotnych w poprzednim okresie wpływał na podniesienie stopy wzrostu liczby bezrobotnych zarówno mężczyzn, jak i kobiet. W przypadku tego parametru rozbieżności nie były aż tak duże jak w warunkach nierosnącego bezrobocia, przy czym tym razem silniej na przyrost bieżącej stopy wzrostu bezrobotnych oddziaływał poziom bezrobocia w poprzednim okresie wśród mężczyzn niż wśród kobiet. Istotnie zróżnicowana była przede wszystkim elastyczność bezrobocia względem produkcji sprzedanej przemysłu wśród kobiet i mężczyzn. Oznacza to, że wzrost stopy produkcji sprzedanej przemysłu o 1 punkt procentowy powodował spadek tempa wzrostu bezrobotnych o 0,26 punktu procentowego wśród mężczyzn i o 0,06 punktu procentowego wśród kobiet. Uzyskana elastyczność bezrobocia względem produkcji sprzedanej przemysłu była ponad 4,3-krotnie wyższa wśród mężczyzn niż wśród kobiet. Oznacza to, że bezrobocie wśród mężczyzn zdecydowanie silniej reagowało na zmiany koniunkturalne na rynku towarowym. Bezrobocie wśród mężczyzn było zatem bardziej procykliczne niż wśród kobiet.

- Elastyczność bezrobocia względem produkcji sprzedanej była również istotnie zróżnicowana, biorąc pod uwage grupy bezrobotnych ze względu na poziom wykształcenia. Najwyższą elastyczność uzyskano w grupie bezrobotnych z wykształceniem wyższym $(-0,25)$. W grupie bezrobotnych $\mathrm{z}$ wykształceniem średnim ogólnokształcącym oraz zasadniczym zawodowym uzyskano podobne poziomy elastyczności (odpowiednio 0,1495 i -0,1506). Najniższy poziom elastyczności uzyskano w grupie bezrobotnych z wykształceniem policealnym i średnim zawodowym $(-0,1225)$. W przypadku bezrobotnych $\mathrm{z}$ wykształceniem gimnazjalnym i poniżej uzyskany parametr był nieistotny statystycznie.

- Biorąc pod uwagę wiek zarejestrowanych bezrobotnych, okazuje się, że zdecydowanie wyższą elastycznością względem produkcji sprzedanej cechowała się grupa „młodych” bezrobotnych. Elastyczność w grupie bezrobotnych w wieku 24 i mniej wyniosła -0,22, natomiast wśród bezrobotnych w wieku 25 i więcej lat $-0,12$. Taka różnica może wynikać z kilku powodów. Po pierwsze, bezrobotni w wieku 24 i mniej lat stanowili ok. 1/4 wszystkich bezrobotnych. Po drugie, starsi bezrobotni zazwyczaj mają doświadczenie zawodowe oraz większy staż pracy, co stawia ich w uprzywilejowanej sytuacji na rynku pracy. Po trzecie, wyższa elastyczność oznacza, że gdy koniunktura się poprawia, to więcej bezrobotnych znajduje zatrudnienie, ale gdy nadchodzi recesja, to częściej pracę tracą „młodzi” z krótkim stażem pracy. Ogólnie rzecz ujmując, młodzi bezrobotni w wieku do 24 lat są bardziej procykliczni niż bezrobotni powyżej 25. roku życia.

- Różną elastycznością bezrobocia względem produkcji sprzedanej przemysłu charakteryzowali się bezrobotni ze względu na miejsce zamieszkania. W przypadku tych kategorii bezrobotnych wyższą elastyczność uzyskano wśród bezrobotnych zamieszkałych w mieście $(-0,13)$ niż wśród bezrobotnych zamieszkałych na wsi $(-0,11)$. Jednakże w przypadku tych grup rozpiętość elastyczności była niewielka. Na uwagę zasługuje jednak kwestia po pierwsze, że prawie $2 / 3$ wszystkich bezrobotnych w województwie mieszka na wsi. Po drugie, na wsi istnieje dość duża grupa bezrobocia ukrytego, gdyż cześć osób, którzy stracili pracę, nie mogą się zarejestrować w Urzędzie Pracy ze względu na posiadanie użytków rolnych. 


\section{PODSUMOWANIE I WNIOSKI}

Prowadzone w artykule rozważania można zatem podsumować następująco:

1. Większy udział w ogólnej liczbie bezrobotnych w latach 2003-2011 w województwie podkarpackim stanowiły kobiety - średnio 53\%, mężczyźni zaś - 47\%. Ponadto struktura bezrobotnych, biorąc pod uwagę płeć, była istotnie zróżnicowana na poziomie powiatów.

2. Dezagregując poziom bezrobocia na Podkarpaciu ze względu na poziom wykształcenia, stwierdzono, że bezrobotni z wyższym wykształceniem cechowali się najniższym udziałem w ogólnej liczbie pozostających bez pracy. Stanowili bowiem ok. 8,3\% wszystkich bezrobotnych w województwie. Niskim udziałem charakteryzowała się też grupa bezrobotnych z wykształceniem średnim ogólnokształcącym $(8,8 \%)$. Średnim udziałem (ok. 25\%) cechowali się bezrobotni z wykształceniem policealnym i średnim zawodowym oraz grupa bezrobotnych $\mathrm{z}$ najniższym poziomem wykształcenia (gimnazjalne i poniżej). Najwyższy udział w ogólnej liczbie bezrobotnych zanotowano wśród bezrobotnych z wykształceniem zasadniczym zawodowym (ok. 33,4\%). Na przestrzeni badanych lat okazuje się, że struktura bezrobotnych w województwie podkarpackim zmienia się. Wynika to $\mathrm{z}$ tego, że udziały bezrobotnych $\mathrm{z}$ wykształceniem wyższym oraz średnim zwiększały się, przy czym najszybciej rosły wśród bezrobotnych z wykształceniem wyższym. Natomiast udziały bezrobotnych z wykształceniem zasadniczym zawodowym oraz gimnazjalnym i poniżej spadały. Może to wynikać z tego, że po pierwsze, zmienia się ogólna struktura wykształcenia i coraz większy odsetek populacji charakteryzuje się wyższym poziomem wykształcenia. Po drugie, jeżeli rośnie ogólna liczba osób z wykształceniem wyższym oraz średnim, to naturalne jest, że coraz większe problemy mają ze znalezieniem odpowiedniej pracy, przez co wzrasta udział tych grup bezrobotnych w ogólnej liczbie bezrobotnych.

3. Wysoki udział, bo około $1 / 4$, stanowiły tzw. „młodzi bezrobotni” w wieku do 24 lat włącznie. Jednocześnie ta grupa bezrobotnych charakteryzowała się malejącymi udziałami w okresach dobrej koniunktury (wtedy też stopy bezrobocia spadały), a rosły w okresach recesji gospodarczej.

4. Średnio $2 / 3$ bezrobotnych w województwie podkarpackim to osoby zamieszkujące obszary wiejskie. Natomiast zaledwie $1 / 3$ spośród bezrobotnych to mieszkańcy miast, przy czym średnia stopa urbanizacji województwa podkarpackiego wynosiła około $41 \%$.

5. Analizując elastyczność bezrobocia względem produkcji sprzedanej przemysłu brutto, okazuje się, że zdecydowanie wyższą elastycznością cechują się bezrobotni mężczyźni niż kobiety (współczynnik elastyczności 4,3-krotnie wyższy wśród mężczyzn niż wśród kobiet). Najwyższą elastycznością bezrobocia względem produkcji sprzedanej charakteryzowali się bezrobotni z wykształceniem wyższym (elastyczność -0,25). Średni poziom elastyczności uzyskano $\mathrm{w}$ grupie bezrobotnych $\mathrm{z}$ wykształceniem zasadniczym zawodowym oraz średnim ogólnokształcącym (współczynnik elastyczności -0,15). Najniższy poziom elastyczności odnotowano wśród bezrobotnych z wykształceniem policealnym oraz średnim zawodowym $(-0,12)$.

6. Wyniki uzyskane wśród bezrobotnych pogrupowanych ze względu na wiek wskazują (co potwierdzają obserwacje z punktu 1.3), że prawie dwukrotnie wyższym poziomem elastyczności bezrobotnych względem produkcji sprzedanej brutto charakteryzowali się 
tzw. „młodzi bezrobotni” (współczynnik elastyczności -0,22) niż grupa bezrobotnych w wieku 25-67 lat (współczynnik elastyczności -0,12).

7.W grupach bezrobotnych zamieszkałych na wsi i w mieście uzyskane współczynniki elastyczności były zbliżone i wynosiły odpowiednio -0,11 dla zamieszkałych na wsi oraz $-0,13$ dla zamieszkałych w mieście.

8. Wydaje się zatem, że dokładne określenie, która grupa bezrobotnych cechuje się najwyższym (bądź najniższym) poziomem elastyczności względem zmian na rynku towarowym, może stanowić podstawę rekomendacji dla racjonalnej polityki państwa na ryn$\mathrm{ku}$ pracy w okresach recesji gospodarczych. Pozwala to lepiej skoordynować odpowiednie instrumenty np. aktywnej polityki państwa w walce $\mathrm{z}$ bezrobociem do odpowiedniej grupy bezrobotnych.

\section{LITERATURA}

[1] Bartosik K., Popyt na prace $w$ Polsce $w$ warunkach spowolnienia gospodarczego, „Studia Ekonomiczne" LXX/3 (2011).

[2] Czyżewski A.B., Wzrost gospodarczy a popyt na prace, „Bank i Kredyt” 2002/11-12.

[3] Kwiatkowski E., Kryzys globalny a rynek pracy w Polsce i innych krajach Grupy Wyszehradziej, „Ekonomista” 2011/1.

[4] Kwiatkowski E., Kucharski L., Tokarski T., Bezrobocie i zatrudnienie a PKB w Polsce w latach 1993-2001, „Ekonomista” 2002/3.

[5] Kwiatkowski E., Gajewski P., Tokarski T., Determinanty popytu na prace $w$ teorii ekonomii, [w:] System prognozowania popytu na prace w Polsce. Podstawowa metodologia, „Studia i Materiały RCSS" 2003/XI.

[6] Misiak T., Tokarski T., Wzrost PKB a zmiany zatrudnienia i bezrobocia w krajach Unii Europejskiej, ,Folia Oeconomica” 2011/248.

[7] Pindyck R.S., Rubinfeld D.L., Econometric Models and Economic Forecast, McGraw-Hills, New York 1991.

[8] Rogut A., Determinanty popytu na prace w Polsce $w$ okresie transformacji, Wydawnictwo Uniwersytetu Łódzkiego, Łódź 2008.

[9] Socha J., Tworzenie i likwidacja miejsc pracy w sektorze przedsiębiorstw w Polsce, „Gospodarka Narodowa" 2006/5-6.

[10] Socha M., Sztanderska U., Strukturalne podstawy bezrobocia w Polsce, Wydawnictwo Naukowe PWN, Warszawa 2000.

[11] Tokarski T., Gajewski P., Zależność między wydajnościq pracy i zatrudnieniem $w$ krajach OECD, „Wiadomości Statystyczne” 2002/8.

[12] Ziomek A., Produkt krajowy a bezrobocie, Wydawnictwo Wyższej Szkoły Bankowej, Poznań 2006.

\section{STRUCTURE OF REGISTERED UNEMPLOYMENT IN PODKARPACKIE PROVINCE VERSUS CHANGES IN THE COMMODITY MARKET}

This paper analyzes the relationship between the commodity market and the structure of unemployment in Podkarpacie Province. The main objective of this paper is to determine the direction and strength of the impact of cyclical changes in the commodity market on the structure of the unemployed in the analyzed region. The structure of the unemployed individuals was analyzed for gender, level of education, age and place of residence. The verification of the conclusions of the theoretical analysis of the impact of changes in commodity market on the unemployment structure was based on panel data from 25 counties in Podkarpackie Province between 2003-2011. In addition, there was also presented a simple theo- 
retical model in which the growth rates of registered unemployment (in this paper replaced by the growth rates of unemployment) in the coming years depend on past values of these rates, as well as depend on the growth rates of production at the level of counties. The analytical model was estimated by means of the procedure of variation of the fixed effects, since it turns out that the structure of the unemployed at the level of counties in Podkarpackie Province exhibits a high degree of spatial heterogenity and switching dummy variables. The introduction of the dummy variables stems from the fact that they act as a corrective variables which change the impact of unemployment registered in the previous period on change in the current growth rate of the unemployed and depend on the rising or declining rate in unemployment.

The structure of this work is as follows. The second part was a descriptive analysis of the structure of unemployed in Podkarpackie Province by: gender, level of education, age and place of residence. The third section presents a simple theoretical model of the relationship between unemployment and commodity market. Section four provides the results of estimating equations resulting from the theoretical analysis. The paper concludes with the fifth point that contains the summary and conclusions of the more important considerations.

Keywords: unemployment, structure of unemployment, Podkarpackie Province.

DOI: 10.7862/rz.2013.mmr.50

Tekst złożono w redakcji: maj 2013

Przyjęto do druku: grudzień 2013 